\title{
Basic Science: (June 2006)
}

1. Adams SA, Matthews CE, Hebert JR, Moore CG, Cunningham JE, Shu XO, Fulton J, Gao YT, Zheng W. Association of physical activity with hormone receptor status: the Shanghai Breast Cancer Study [Abstract]. Cancer Epidemiol BiomarPrev 2006; 15: 1170-1178.

2. Bandyopadhyay S, Zhan R, Wang Y, Pai SK, Hirota S, Hosobe S, Takano Y, Saito K, Furuta E, liizumi M, Mohinta S, Watabe M, Chalfant C, Watabe K. Mechanism of apoptosis induced by the inhibition of fatty acid synthase in breast cancer cells [Abstract]. Cancer Res 2006; 66: 5934-5940.

3. Blakely CM, Stoddard AJ, Belka GK, Dugan KD, Notarfrancesco KL, Moody SE, D'Cruz CM, Chodosh LA. Hormone-induced protection against mammary tumorigenesis is conserved in multiple rat strains and identifies a core gene expression signature induced by pregnancy [Abstract]. Cancer Res 66: 6421-6431.

4. Cellai C, Laurenzana A, Vannucchi AM, Caporale R, Paglierani M, Di Lollo S, Pancrazzi A, Paoletti F. Growth inhibition and differentiation of human breast cancer cells by the PAFR antagonist WEB-2086 [Abstract]. Brit J Cancer 2006; 94: 1637-1642.

5. Cui YK, Parra I, Zhang M, Hilsenbeck SG, Tsimelzon A, Furukawa T, Horii A, Zhang ZY, Nicholson RI, Fuqua SAW. Elevated expression of mitogen-activated protein kinase phosphatase 3 in breast tumors: A mechanism of tamoxifen resistance [Abstract]. Cancer Res 2006; 66: 5950-5959.

6. den Hollander P, Kumar R. Dynein light chain 1 contributes to cell cycle progression by increasing cyclin-dependent kinase 2 activity in estrogen-stimulated cells [Abstract]. Cancer Res 2006; 66: 5941-5949.

7. Dieudonne MN, Bussiere M, Dos Santos E, Leneveu MC, Giudicelli Y, Pecquery R.

First published online 30/08/06 BCO/567/2006/JW
Adiponectin mediates antiproliferative and apoptotic responses in human MCF7 breast cancer cells [Abstract]. Biochem Biophys Res Commun 2006; 345: 271-279.

8. Doane AS, Danso M, Lal P, Donaton M, Zhang L, Hudis C, Gerald WL. An estrogen receptornegative breast cancer subset characterized by a hormonally regulated transcriptional program and response to androgen [Abstract]. Oncogene 2006; 25: 3994-4008.

9. Faupel-Badger JM, Prindiville SA, Venzon D, Vonderhaar BK, Zujewski JA, Eng-Wong J. Effects of raloxifene on circulating prolactin and estradiol levels in premenopausal women at high risk for developing breast cancer [Abstract]. Cancer Epidemiol Biomar Prev 2006; 15: 1153-1158.

10. Glinsky GV. Genomic models of metastatic cancer - Functional analysis of death-from-cancer signature genes reveals aneuploid, anoikis-resistant, metastasis-enabling phenotype with altered cell cycle control and activated polycomb group (PcG) protein chromatin silencing pathway [Abstract]. Cell Cycle 2006; 5: 1208-1216.

11. Hiscox S, Morgan L, Green TP, Barrow D, Gee J, Nicholson RI. Elevated Src activity promotes cellular invasion and motility in tamoxifen resistant breast cancer cells [Abstract]. Breast Cancer Res Treat 2006; 97: 263-274.

12. Jechlinger $M$, Sommer $A$, Moriggl $R$, Seither $P$, Kraut N, Capodiecci P, Donovan M, Cordon-Cardo C, Beug H, Grunert S. Autocrine PDGFR signaling promotes mammary cancer metastasis [Abstract]. J Clin Invest 2006; 116: 1561-1570.

13. Kataoka N, Cai QY, Wen WQ, Shu XO, Jin F, Gao YT, Zheng W. Population-based case-control study of VEGF gene polymorphisms and breast cancer risk among Chinese women [Abstract]. Cancer Epidemiol Biomar Prev 2006; 15: 1148-1152.

14. Kijima I, Phung S, Hur G, Kwok SL, Chen SU. Grape seed extract is an aromatase inhibitor and a suppressor of aromatase expression [Abstract]. Cancer Res 2006; 66: 5960-5967. 
15. Klinakis A, Szaboics $M$, Politi $K$, Kiaris $H$, Artavanis-Tsakonas S, Efstratiadis A. Myc is a Notch1 transcriptional target and a requisite for Notch1-induced mammary tumorigenesis in mice [Abstract]. Proc Natl Acad Sci USA 2006; 103: 9262-9267.

16. Landis MD, Seachrist DD, Abdul-Karim FW, Keri RA. Sustained trophism of the mammary gland is sufficient to accelerate and synchronize development of ErbB2/Neu-induced tumors [Abstract]. Oncogene 2006; 25: 3325-3334.

17. Li SY, Rong MN, lacopetta B. DNA hypermethylation in breast cancer and its association with clinicopathological features [Abstract]. Cancer Lett 2006; 237: 272-280.

18. Li TH, Sotgia F, Vuolo MA, Lo MM, Yang WC, Pestell RG, Sparano JA, Lisanti MP. Caveolin-1 mutations in human breast cancer - Functional association with estrogen receptor alpha-positive status [Abstract]. Am J Pathol 2006; 168: 1998-2013.

19. Li ZP, Wang CG, Jiao XM, Lu YN, Fu MF, Quong AA, Dye C, Yang JG, Dai MZ, Ju XM, Zhang ZP, Li AP, Burbelo P, Stanley ER, Pestell RG. Cyclin D1 regulates cellular migration through the inhibition of thrombospondin 1 and ROCK signaling [Abstract]. Mol Cell Biol 2006; 26: 4240-4256.

20. Linden HM, Stekhova SA, Link JM, Gralow JR, Livingston RB, Ellis GK, Petra PH, Peterson LM, Schubert EK, Dunnwald LK, Krohn KA, Mankoff DA. Quantitative fluoroestradiol positron emission tomography imaging predicts response to endocrine treatment in breast cancer [Abstract]. J Clin Oncol 2006; 24: 2793-2799.

21. Liu SL, Dontu G, Mantle ID, Patel S, Ahn NS, Jackson KW, Suri P, Wicha MS. Hedgehog signaling and Bmi-1 regulate self-renewal of normal and malignant human mammary stem cells [Abstract]. Cancer Res 2006; 66: 6063-6071.

22. Mo R, Rao SM, Zhu YJ. Identification of the MLL2 complex as a coactivator for estrogen receptor alpha [Abstract]. J Biol Chem 2006; 281: 15714-15720.

23. Murphy LC, Watson PH. Is oestrogen receptorbeta a predictor of endocrine therapy responsiveness in human breast cancer? [Abstract]. Endocr Relat Cancer 2006; 13: 327-334.

24. Nam JS, Suchar AM, Kang MJ, Stuelten $\mathrm{CH}$, Tang BW, Michalowska AM, Fisher LW, Fedarko NS, Jain A, Pinkas J, Lonning S, Wakefield LM. Bone sialoprotein mediates the tumor cell-targeted prometastatic activity of transforming growth factor beta in a mouse model of breast cancer [Abstract]. Cancer Res 2006; 66: 6327-6335.
25. Naresh A, Long WW, Vidal GA, Wimley WC, Marrero L, Sartor Cl, Tovey S, Cooke TG, Bartlett JMS, Jones FE. The ERBB4/HER4 intracellular domain $4 \mathrm{ICD}$ is a $\mathrm{BH} 3$-only protein promoting apoptosis of breast cancer cells [Abstract]. Cancer Res 2006; 66: 6412-6420.

26. Rakha EA, Green AR, Powe DG, Roylance R, Ellis IO. Chromosome 16 tumor-suppressor genes in breast cancer [Abstract]. Gene Chromosome Cancer 2006; 45: 527-535.

27. Rayala SK, Molli PR, Kumar R. Nuclear p21activated kinase 1 in breast cancer packs off tamoxifen sensitivity [Abstract]. Cancer Res 2006; 66: 5985-5988.

28. Salvucci O, Bouchard L, Baccarelli A, Deschenes J, Sauter G, Simon R, Bianchi R, Basik M. The role of CXCR4 receptor expression in breast cancer: a large tissue microarray study [Abstract]. Breast Cancer Res Treat 2006; 97: 275-283.

29. Sharma D, Saxena NK, Davidson NE, Vertino PM. Restoration of tamoxifen sensitivity in estrogen receptor-negative breast cancer cells: Tamoxifen-bound reactivated ER recruits distinctive corepressor complexes [Abstract]. Cancer Res 2006; 66: 6370-6378.

30. Smith RA, Lea RA, Weinstein SR, Griffiths LR. Detection of rnRNA levels for the estrogen alpha, estrogen beta and androgen nuclear receptor genes in archival breast cancer tissue [Abstract]. Cancer Lett 2006; 237: 248-255.

31. Souaze F, Dupouy S, Viardot-Foucault V, Bruyneel E, Attoub S, Gespach C, Gompel A, Forgez P. Expression of neurotensin and NT1 receptor in human breast cancer: a potential role in tumor progression [Abstract]. Cancer Res 2006; 66: 6243-6249.

32. Spankuch B, Heim S, Kurunci-Csacsko E, Lindenau C, Yuan JP, Kaufmann M, Strebhardt $\mathrm{K}$. Down-regulation of polo-like kinase 1 elevates drug sensitivity of breast cancer cells in vitro and in vivo [Abstract]. Cancer Res 2006; 66: 5836-5846.

33. Srinivasan D, Plattner R. Activation of Abl tyrosine kinases promotes invasion of aggressive breast cancer cells [Abstract]. Cancer Res 2006; 66: 5648-5655.

34. Stossi F, Likhite VS, Katzenellenbogen JA, Katzenellenbogen BS. Estrogen-occupied estrogen receptor represses cyclin G2 gene expression and recruits a repressor complex at the cyclin G2 promoter [Abstract]. J Biol Chem 2006; 281: 16272-16278.

35. Stredrick DL, Garcia-Closas M, Pineda MA, Bhatti P, Alexander BH, Doody MM, Lissowska J, Peplonska B, Brinton LA, Chanock SJ, 
Struewing JP, Sigurdson AJ. The ATM missense mutation p.Ser49Cys (c.146C > G) and the risk of breast cancer [Abstract]. Hum Mutat 2006; 27: 538-544.

36. Tan M, Li P, Sun M, Yin G, Yu D. Upregulation and activation of PKC alpha by ErbB2 through Src promotes breast cancer cell invasion that can be blocked by combined treatment with $\mathrm{PKCa}$ and Src inhibitors [Abstract]. Oncogene 2006; 25: 3286-3295.

37. To MD, Gokgoz N, Doyle TG, Donoviel DB, Knight JA, Hyslop PS, Bernstein A, Andrulis IL. Functional characterization of novel presenilin-2 variants identified in human breast cancers [Abstract]. Oncogene 2006; 25: 3557-3564.

38. Toyo-oka K, Bowen TJ, Hirotsune S, Li ZR, Jain S, Ota S, Escoubet L, Bassett IG, Lozach J, Rosenfeld NG, Glass CK, Eisenman R, Ren B, Hurlin P, Wynshaw-Boris A. Mnt-deficient mammary glands exhibit impaired involution and tumors with characteristics of Myc overexpression [Abstract]. Cancer Res 2006; 66: 5565-5573.

39. Ueda $Y$, Neel NF, Schutyser E, Raman D, Richmond A. Deletion of the $\mathrm{COOH}$-terminal domain of CXC chemokine receptor 4 leads to the down-regulation of cell-to-cell contact, enhanced motility and proliferation in breast carcinoma cells [Abstract]. Cancer Res 2006; 66: 5665-5675.

40. Vargo-Gogola T, Heckman BM, Gunther EJ, Chodosh LA, Rosen JM. P190-B Rho GTPaseactivating protein overexpression disrupts ductal morphogenesis and induces hyperplastic lesions in the developing mammary gland [Abstract]. Mol Endocrinol 2006; 20: 1391-1405.

41. Veeck J, Niederacher D, An H, Klopocki E, Wiesmann F, Betz B, Galm O, Camara O, Durst M, Kristiansen G, Huszka C, Knuchel R, Dahl E. Aberrant methylation of the Wnt antagonist SFRP1 in breast cancer is associated with unfavourable prognosis [Abstract]. Oncogene 2006; 25: 3479-3488.

42. Wang ZY, Zhang XT, Shen P, Loggie BW, Chang Y, Deuel TF. A variant of estrogen receptor-alpha, hER-alpha 36: Transduction of estrogen- and antiestrogen-dependent membrane-initiated mitogenic signaling [Abstract]. Proc Natl Acad Sci USA 2006; 103: 9063-9068.

43. Yeh YT, Fu OY, Chen IF, Yang SF, Wang YY, Chuang HY, Su JH, Hou MF, Yuan SSF. STAT3 ser727 phosphorylation and its association with negative estrogen receptor status in breast infiltrating ductal carcinoma [Abstract]. Int J Cancer 2006; 118: 2943-2947.

44. Zhang YQ, Zhang BL. D4-GDI, a Rho GTPase regulator, promotes breast cancer cell invasiveness [Abstract]. Cancer Res 2006; 66: 5592-5598.

Prepared by R. Sutherland, J. Scorer Cancer Research Program Garvan Institute of Medical Research Darlinghurst, NSW, Australia 